\title{
Direito Constitucional
}

\author{
A. de Sampaio Doria \\ Democracia diréta e democracia represen- \\ tativa. Coexistência de institutos do governo \\ diréto com o mandato politico.
}

Cumpre distinguir a democracia formal da democracia real. No paiz que tiver instituído a eleição dos dirigentes, assegurado a liberdade de pensamento, e consagrado a egualdade civil e política, a estrutura geral da democracia estará bem lançada. Mas pode acontecer que estes institutos existam apenas no papel. A simples adoção em leis fraudaveis, ou que se não cumprem, não basta á realidade das instituições democráticas.

Ao lado de leis que adotem o regimen democrático, duas cousas são ainda imprescindíveis, para que a democracia exista na prática.

Primeira, é ter o povo o conhecimento exáto do que é o mandato eletivo, do que é a liberdade, e do que é a egualdade.

Segunda, é ter o povo o hábito de se fazer respeitado pelos governantes, na investidura e no exercício do poder.

Da democracia, do mandato político, o homem comum tem uma noção incerta, vaga e confusa. A democracia é, para ele, o governo que desconhece a hereditariedade do poder, o governo aclamado na praça pública, o governo do povo ou representativo. As eleições podem ser uma farç, por falta de leis que organizem o corpo eleitoral, reconheçam a existência dos partidos, garantam ao eleitor a li- 
berdade na votação, assegurem a verdade na apuração eleitoral, e a justiça na proclamação e na posse dos eleitos. Mas, como se processam eleições, é comum supor-se que, só com isto, se institue o mandato político, e, pois, se tem democracia. E' uma noção falsa.

Da liberdade, a confusão não é menor. O que em regra se tem por liberdade, é a faculdade de fazer o que se deseje, o arbítrio sem limites, uma onipotência de ação individual, quando a exata noção da liberdade se ha de enquadrar no poder de fazer ou deixar de fazer o que não desagregue a vida social, nem lhe embarace o desenvolvimento.

Da egualdade, a noção que o povo costuma ter, e que o traz em perpétua revoltà pela sua flagrante contradição com a realidade, é o nivelamento de todos, a indistinção geral, a egualdade raza. Não importa que as leis da vida sejam inteiramente diversas, que, por natureza, sejamos todos desiguais na edade, no sexo, na saude, na força, na capacidade, no caracter. A obsessão do nivelamento material perturba os olhos, para verem o que se conforme com a vida do homem e da sociedade. Nesta orientação, ela consiste, essencialmente, em não se ver ninguem privado de ir até onde puder ir. Consiste, essencialmente, na ausência de privilégios de qualquer natureza, nascimento, riqueza, ou qual for. Dahi, a accessibilidade de todos a todas as funções públicas, e, dahi, o reconhecimento dos méritos que cada qual revele, o que importa desigualdades reais.

Ora, a consciência exáta e viva destes princípios, que essencializam a democracia, distinta das demagogias, e opposta ás autocracias, é produto da educação diuturna e da experiência longa e, por vezes, amarga. Só a religião do direito, e a prática da liberdade vão esclarecendo estes assuntos, para a bôa formação cívica de cidadãos livres.

E a segunda condição: ter o povo o hábito de se fazer ouvido e respeitado pelos dirigentes?

Esta, mais do que a primeira, é resultado de tradições liberais, que $\epsilon$ ncham seculos. Sem lutas com que tenha o 
povo logrado, no aparelhamento do estado, a garantia da sua vida e da sua liberdade contra os excessos de poder, a democracia, mesmo sabiamente instituida, será antes formal que real. A formal costuma ser mercadoria de importação. A real, porem, brota das energias populares, como das raizes subterrâneas a seiva que desabrocha em flores, e amadurece os frutos.

Nos primórdios de qualquer estado, o governo tem sido a lei do mais forte. A hipótese de um contráto social é pueril. Em tempos prehistóricos, é até possivel que os homens, vivendo embora em grupos, não reconhecessem a distinção entre governantes e governados. Tais grupos que se devem ter formado por si mesmos, sem plano preestabelecido, não eram propriamente estados. Hão de ter, porém, verificado, muito cedo, as desvantagens da ausência de governo. Para apasiguar as rixas entre os membros do mesmo grupo, que deviam ser terriveis e constantes, e para comandar as forças nas guerras dos grupos entre si, que deveriam ter sido tambem constantes e crueis, se havia de ter imposto, sem grande demora, e como recurso de salvação geral, a subordinação de todos a um chefe. Mas a determinação deste chefe devia de ter sido, nestes primórdios, a lei do mais forte.

Com a civilização, porém, os homens foram compreendendo que a força, so por si, não legitima o poder, e que o poder se institue não para a satisfação dos dirigentes, mas para o bem do povo que os sustenta. Dahi, sempre que as circumstâncias tenham sido propícias, as reacções liberais contra o poder despótico. A gênese e o desenvolvimento do parlamento inglez são, talvez, da realidade democrática, o mais expressivo exemplo de reivindicação progressiva dos direitos do homem contra prerogativas usurpadoras das autocracias. $\mathrm{O}$ habito de se fazer respeitado na investidura e no exercício do poder, como condição da realidade democrática, não foi, por certo, tarefa de um só dia; mas trabalho de gerações sucessivas. 
E' preciso que, constituindo governantes, se faça o povo por eles respeitados nos seus direitos, mesmo a pesar daqueles. Não, apelando para a violência das armas, para o terror dos atentados, ou para a crueza das guerras. Tudo isto é precário. O que importa, é aparelhar-se o estado com instrumentos da vontade popular, e, paralelamente, organizar-se o povo em partidos, que, pelo apoio ou pela oposição, compondo ou renovando ministérios e câmaras, não deixe nunca o povo de ser o governo de si mesmo, apesar da representação política, que institua. Então, o povo que já tenha aprendido o que é a democracia, terá tambem o hábito sadio de se fazer respeitar pelas suas próprias mãos, sem o apelo ás revoluções.

Como, porém, ha de um povo aparelhar o estado que realize, com perfeição relativa, a democracia real?

Preliminarmente, repelirá toda e qualquer transação com sistemas autocráticos. Ha de devotar-se de corpo e alma á organisação prática da sua democracia. Não de qualquer, mas da que lhe calhe, da que lhe vá bem. A que dér certo em um povo, pode malograr em outro. E' preciso atender ás diferenças de raças e culturas, ás condições geográficas e econômicas de cada povo. A democracia parlamentar é admiravel na Inglaterra, na França ou na Bélgica. Seria, nos Estados Unidos, talvez, um desastre, por via de sua federação, das suas condições geográficas, e da variedade de raças do seu povo. Ahi tem sido magnifica a democracia presidencial, que a Libéria não poude realizar. Mas já não convem talvez á França ou á Inglaterra.

Antes, porém, de escolher esta ou aquela forma demo. crática, a parlamentar, presidencial, a colegial, ou outra, cumpre optar ou pelo governo direto, ou pelo sistema representativo.

Democràcia diréta, ou governo diréto, é aquele em que o povo, num apego supersticioso á soberania, resolve, por si mesmo, sem intermediários, os problemas fundamentaes do seu destino coletivo. De tempos a tempos, o povo se con- 
voca, para elaborar, como the aprouver, as suas leis. 0 poder de as fazer, não o comete ele a ninguem; ele o exerce em pessôa.

Depois, como é preciso que permaneça alguem á testa dos negócios públicos, escolhe o povo funcionários encarregados de aplicar as leis que tenha votado. Não escolhe representantes que queiram por ele, ou mesmo queiram com ele, ou como ele. Na democrácia diréta, quem quer é sempre, em sí mesmo, o povo soberano. Os governantes que o povo designe, são apenas funcionários que lhe cumprem rigorosamente as ordens, as suas ordens, como soberano, que é, e não póde deixar de ser.

E' assim a democracia diréta, a democracia pura, como se esforçaram por praticar os atenienses, na antiguidade.

$O$ povo se reune na praça pública, e, ahi, os assuntos que lhe interessam, são discutidos, e, como resultado da discussão, votadas as leis que the disciplinem a vida coletiva. As épocas de convocação para estas assembleias, a maneira como funcionam, o processo de votação, a redação do vencido, tudo isto o povo mesmo determina previamente em leis.

Em vez da reunião em praça pública, ou em teatros, mercados ou ágoras, podem as deliberações do povo ser tomadas em casa, sem a confusão e os inconvenientes das multidões. Basta, para isto, que os negócios públicos, suscitados com antecedência, sejam livremente discutidos nas palestras, na imprensa, no livro, e, hoje, no rádio; em seguida, em dia certo, e segundo processo assentado pelo povo, se apure como quer a vontade nacional que eles sejam resolvidos. Será, então, a lei.

Quer reunidos na praça pública, quer convocados a examinar e a votar os problemas, sempre é o povo soberano que diretamente delibera. E, por esta fórma, não obedecendo o cidadão a nenhum outro homem, mas tão somente cada um a si mesmo, na lei que apure a opinião dominante, o povo é verdadeiramente livre. 
E não se cuide que a democracia direta é pura especulação, aspiração meramente teórica.

Nalgumas regiões da Suissa, em tempos idos, os homens se reuníam na praça pública, para deliberar sobretudo o que interessasse a todos. A landsgmeind, como orgão legislativo supremo, ainda hoje, subsiste nos cantões e subcantões de Obwald, Nidwald, Glavis, Appenzell-Rhodes-interiores, e Appenzell-Rhodes-exteriores. E' uma instituição genuina de democracia diréta.

Periodicamente, pelo menos uma vez por ano, todos os cidadãos ativos se reunem, para a solução dos problemas mais importantes da coletividade. Nestas reuniões, podem reformar a constituição, eleger magistrados, adotar leis, instituir e modificar impostos, autorizar empréstimos públicos, votar despezas, criar e suprimir empregos, e lhes fixar os vencimentos. A landsgmeind, que subsiste em cantões da Suissa, coexiste com um governo eleito, superpondo-se, porem, a ele, como instância suprema, inapelavel, última. As assembleias legislativas e os conselhos executivos, que constituem o governo eleito, nada podem deliberar em definitivo, sem audiência da landsgemeind. Rousseau, que, aliás, era suisso, tinha os olhos postos nesta organização de democracia mixta, quando, repassado de um respeito sagrado pela soberania popular, se insurgia contra a representação política, que delibere em definitivo.

E' realmente um governo que se recomenda por algumas vantagens.

Eis as maiores.

Primeiro, a pureza, a integridade, a intangibilidade da soberania. Só no governo diréto, ela não se desvirtúa. A soberanía, argumenta Rousseau, ou é ela mesma ou é outra cousa; não ha meio termo. Sempre que o povo não exerça diretamente, ela deixa de ser ela mesma, passa a ser outra cousa, que the usurpa o nome. Na formação histórica dos 
estados, com a predominância usual dos mais fortes, a soberania vive confiscada, ou, para dizer tudo, ela não existe senão de nome. $O$ que ha de fáto, é o poder pessoal do mais forte. Só quando a civilização política se apure, é que emerge a soberania legítima, a verdadeira, a soberania do povo. E esta, para que não se desvirtue, não se concilía com a representação. A representação importa sempre em uma alienação periódica da soberania. 0 que o povo elege fóra da democracia diréta, é, na verdade, indivíduos que querem por ele, em vez de the cumprirem as ordens. Só ha um meio para evitar que a soberania deixe de ser ela mesma, intangivel, integra, pura, argumentam os partidários da democracia diréta: é que não seja delegada.

Segunda vantagem da democracia diréta é a da legitimidade inquestionável da lei. Na representação política, os governantes fazem as leis sem audiência do povo, e, muitas vezes, contra a vontade do povo. Na diréta, não. É o povo mesmo, reunido, que cristaliza em lei o que quer. Dir-se-á que, mesmo na democracía diréta, as deliberaçãos populares são a vontade da maioria, e só a unanimidade conciliaria a liberdade individual com a subordinação á lei. A objeção exagéra. Em primeiro logar, unanimidade entre homens não é de esperar. As divergências de opinião são incontáveis. A variedade é o que é natural. Em segundo logar, é justo, ou pelo menos necessário, que a maioria delibere. A maioria não se compõe sempre das mesmas pessôas; não ha ninguem com o privilégio de membro da maioria. E' da maioria quem o queira ser. Os que estão hoje em minoria numa votação, podem compor a maioria na votação seguinte; êles se revezam. Em terceiro logar, a maioria que por natureza se recompõe sem cessar, não tem nenhum interesse em se prejudicar, votando leis lesivas á mi. noria, pois que a lei é egual para todos. 0 que for contrário á minoria, é egualmente nocivo á maioria. A egualdàde de todos perante a lei dá ao princípio majoritário, na elaboração das leis, legitimidade inquestionável. $\mathrm{E}$ por isto ninguem se revolta contra as leis. Reconhecem todos, nelas, a. 
vontade do povo. Quando inquinadas de erros ou mal feitas, o povo que as fez, não tardaria em revogal-as ou modifical-as, pois é a sua vontade o que predomina. As rebeldias não chegam a esboçar-se.

Terceira vantagem da democracia diréta é o ensejo que, com ela, o povo tem, de firmar e apurar, com mais eficiência, a capacidade de se governar por si mesmo. Cada cidadão vae adquirindo o hábito de examinar e refletir as questões de interesse geral, e agir em conseqüência. Com a representação política, este hábito tambem se pode formar. Mas apenas para apreciar e escolher quem resolva em seu nome, ou criticar as resoluções que, em seu nome, tomem. Ao passo que, na democracia diréta, não só o povo se habitua a examinar os problemas gerais, opinar sobre a solução que devem ter, como se habitua a resolver por si mesmo, de acôrdo com o parecer, claro está que tenha.

Quarta vantagem é a aproximação, que o governo diréto proporciona, de uma egualdade social mais perfeita. Com o trato em comum dos negócios públicos, os cidadãos se aproximam, trocam idéas, convivem mais de perto, melhor se compreendem. Destes contactos se vão limando as arestas das diferenças sociais, em benefício da cooperação, que harmoniza, em vez da competição que separa, e acentúa as diferenças sociais.

$\mathrm{E}$, assim, outras vantagens.

Se fosse de realização facil, e se a realidade correspondesse ás aparências, nenhum governo teria realmente a pureza da democracia diréta. Nada de representantes, nada de chefes, nada de tutores, nem mesmo por tempo determinado. $\mathrm{O}$ povo, no conhecimento diréto de seus problemas, tomaria a iniciativa das soluções que lhe parecessem mais adequadas.

Não obstante, a democracia em que o povo delibere reunido na praça pública, não deixou saudades na história.

Sabe-se que as multidões agem diferentemente dos indivíduos que as compõem. 0 que cada homem pensa e se 
deixa ir, ou se precipita em assembléias, na praça pública, não é o que, sobre o mesmo assunto, ele mesmo pensa, sente e resolveria isoladamente, em casa. As multidões se distinguem dos indivíduos por caracteres próprios, como a credulidade infantil, a susceptibilidade fácil, a impulsividade pronta para todos os excessos. Além disto, costuma a multidão estar sob uma expectativa impulsiva, quasi sempre trabalhada por um interesse que a traz agitada. A preguiça de pensar, e o contágio dos sentimentos subtráem aos indivíduos a liberdade de agir por sua cabeça. Deixam-se todos acorrentar a uma força anônima, a uma violência de sentimentos que lhes perturbam o senso crítico. Só uma cousa predomina na multidão rumorosa e agitada: a incapacidade de raciocinar serenamente, e a facilidade de cometer crimes, embora haja nela indivíduos incapazes da menor incorreção moral. 0 que se comunica insensivelmente ás multidões, não é a convicção que decorra da análise fria dos fátos, do julgamento imparcial das cousas e dos homens. Mas, a vivacidade das imagens que encantam, as apóstrofes retumbantes, que estremecem, a sugestão dos sentimentos que apaixonam. 0 orador da rua, que lisongeia os baixos instintos do povo, para fazel-o instrumento de suas ambições políticas, que afirma sem reservas, que impreca sem tolerâncias, não perdôa, não transige e não esquece, exigindo tudo ou nada, leva de vencida o orador comedido, que prefere falar mais á razão que ás paixões, que distingue, que admite dúvidas, que dispensa na fraqueza humana, e mede, por sinceridade, a extensão do que propõe.

Acrescente-se a tudo isto a irresponsabilidade do número, a cuja sombra não ha quasi quem não se acolha. A responsabilidade do que fazem as multidões, se dilue na massa anônima, e ninguem se sente na culpa dos erros e crimes que elas cometam. Quando chamado a contas, se esgueira cada um na tangente de ter sido contra o que não tiver dado certo.

Em resumo, as deliberações da massa popular, na praça pública, são o que forem as paixões dos poucos que a con- 
duzirem. E se alguma vez forem certas, isto será pela soberania do acaso.

Tem-se dito que a democracia diréta pode substituir as reuniões na praça pública, por consultas gerais, em que deliberem todos com calma, votem em dia certo, após discussão pela imprensa, pelos livros, nos comícios, e, hoje, até pelo rádio. 0 povo se inteiraria, no debate prévio, do que vae resolver soberanamente. $\mathrm{E}$ as suas deliberações se livrariam, por esta fórma, dos males inherentes ás multidões.

Subsistiriam, ainda assim, grandes inconvenientes.

Em primeiro logar, os assuntos não seriam ventilados sob todos os aspectos nos mesmos jornais, livros, cursos, conferências ou radiações. Seria preciso que -ada cidadão lesse os jornais e os livros de todos os cre s, ouvisse os professores e oradores de todos os partidos. Ora, sobre serem poucos os que lêm ou ouvem, cada qual só lê, em regra, o seu jornal, ou só escuta, de ordinario, a voz de seu partido. Não examina cada individuo todos os aspectos do mesmo problema, os prós e os contras, o verso e o reverso. E a consequência é não ficar ninguem perfeitamente seguro dos problemas para cujas soluções vae dar o seu voto.

Em segundo logar, o povo, sem o hábito das leituras sérias, não dispõe, nas duras preocupações da vida, cada vez mais complicada, com que luta, vagares e calma para a meditação serena e imparcial das cousas públicas. As opiniões que chegue a formular, serão provavelmente sem firmeza, irrefletidas e sofísticas.

E, em terceiro logar, faltam ao povo, ainda que tivesse tempo bastante, conhecimentos especializados dos assuntos complexos do governo. Ninguem é versado em tudo, para opinar em tudo, como em seara própria.

O sistema, pois, da democracía diréta, que substituisse a multidão rumorosa na rua, pela votação plebiscitária, após discussão pública, esbarra com esta séria objeção: a incapacidade prática, visceral, irremessível do povo, para de- 
liberar com acerto, diretamente, sobre os mais complexos negócios de estado.

“O povo, já notava Montesquieu, no Espírito das Leis, (Liv. II, cap. II) é admiravel para escolher aqueles a quem deve confiar certas prerogativas da sua autoridade". Ele póde escolher bem um general, um juiz, graças a informações que colhe na praça pública, e com as quais póde acertar melhor do que "um monarca em seu palácio". "Mas saberá ele encaminhar um negócio, conhecer a lei, as ocasiões, os momentos, e deles aproveitar-se? Não; ele não o saberá". Além disto, é ainda Montesquieu quem fala: "é preciso que os negócios andem e que andem com certo movimento, nem muito devagar, nem muito depressa. Mas o povo tem sempre ora excesso ora escassez de ação. Algumas vezes, com cem mil braços, ele desmorona tudo; outras vezes, com cem mil pés, ele anda como insectos".

Reconhecer aliás, no povo, incapacidade para exercer diretamente a soberania não é cousa que o desdoire. Cada um de nós é tambem incapaz de resolver grande numero de problemas da própria vida. Se eu me abalasse, quando enfermo, a diagnosticar-me, e a me prescrever o regimen de cura, certo, não sendo eu clínico, iria á garra. Que devo fazer para me restabelecer a saude? Incapaz de diagnosticar e receitar por mim mesmo, sou, contudo, capaz de escolher um médico que diagnostique bem, por mim, e me receite remédios eficazes. Assim para tantos outros problemas individuais. Quero construir uma casa; mas, não sendo arquitecto, que hei de fazer? Avençar, é claro, com um técnico a construção da casa. Não sendo alfaiate, e, precisando vestir-me, que me cumpre fazer? Sou incapaz de cortar eu mesmo a roupa de que preciso. Mas sou capaz de escolher um oficial, que m'as faça bem. Todos nós somos capazes de escolher quem faça bem por nós, e incapazes de fazer bem, por nós mesmos, numerosas cousas. A regra geral de cada qual é cometer a outrem tudo o que por si mesmo não possa fazer a tempo, a hora, e bem. 
Com maiores razões, o povo. Os problemas da coletividade são mais complexos e mais difíceis que os problemas individuais. $O$ povo não tem competência para os resolver com acerto por si mesmo. Não sabe, por exemplo, que solução dar ao problema da moeda, ao problema do seu comércio com outros povos, como resolver a primor a educação pública, a higiene pública, e assim por deante. Ninguem é enciclopédico. Mas é capaz o povo de escolher, mais ou menos bem, técnicos, administradores, condutores, dirigentes. Incapaz de resolver bem, diretamente, os negócios públicos, é idôneo para escolher bem quem por ele os resolva. Tem inteligência bastante, para julgar a gestão dos outros, embora não a tenha, para gerir por si mesmo.

Mas, como para os indivíduos, só deve o povo confiar aos outros o que não puder fazer por si mesmo. Ou, como se expressa Montesquieu, na mesma obra, "o povo soberano deve fazer por si mesmo tudo o que puder bem fazer; e o que não n'o puder, cumpre que o faça por intermédio dos magistrados que eleja".

A observação dos fátos nos leva, pois, a reconhecer, no regimen representativo, vantagens práticas sobre o governo diréto. Aliás, o governo diréto não vingou perdurar. Onde foi instituido, e levou séculos de preparação e aperfeiçøamento, tombou de repente, sem esperança de resurgir.

O menor mal está, sem dúvida, na representação política.

A representação política consiste em cometer o povo a certos indivíduos o encargo dos negócios públicos. 0 povo escolhe os governantes, e estes governam com o povo. As suas decisões obrigam o povo, como se este mesmo tivesse diretamente decidido.

Nem sempre a representação política tem tido a mesma amplitude. Sobre o mandato que os representantes recebem do povo, se extremam pelo menos duas concepções.

Uma é a de que o representante, o governante escolhido, o dirigente eleito, fica, pelo mandato que receba, com o direito de querer pelo povo. Uma vez eleito, exerce o poder 
como the pareça, com absoluta liberdade, a seu inteiro arbítrio. 0 que fizer, é lei, que, por tal, se impõe ao povo, como se o povo mesmo a tivesse feito de primeira mão. A soberania se subroga, por assim dizer, da vontade do povo, para a vontade dos governantes. A soberania nacional só é exercida diretamente, quando o povo elege representantes. E', no fundo, uma alienação periódica do povo ás camadas dirigentes.

A segunda concepção do mandato político é de menor amplitude. 0 povo escolhe, não senhores, mas delegados seus, gestores de seus interesses, procuradores dos seus negócios. Os eleitos, representantes do povo, deputados ou senadores, governadores ou presidentes, não querem pelo povo, mas querem com o povo, ou como o povo. Tal no mandato em direito privado. Aceita um advogado procuração de um cliente, para lhe pleitear, em juizo, um direito. Pode o advogado, tratando-se de abrir mão desse direito, querer pelo cliente? Ou terá de querer de acôrdo com ele? Certo, em matéria de técnica profissional, o advogado age como entenda. Mas, em matéria do direito que advoga, dos interesses cuja garantia pleiteia, ou estará sempre com o seu cliente, ou lhe estará traíndo a confiança. Se houver entre o procurador e o cliente desacordo sem solução em sustentar ou transigir o direito que este sustenta, o dever do procurador é renunciar a procuração, para não traír a confiança com que o elegeu o seu constituinte. Nada mais nem menos, no mandato político. E' um cidadão eleito por um partido, ou uma corrente de opinióes, para exercer o mandato legislativo ou executivo. Terá ele que dar solução aos problemas públicos, que forem surgindo. Poderá, na solução que der a qualquer deles, agir contra o seu partido ou corrente de opinião que o tenha elegido? Isto é, poderá querer pelo povo? Ou o que lhe cumpre, é estar sempre de acôrdo com os que o elegeram, com o povo, ou como os seus eleitores? Na maneira de agir, tem absoluta liberdade. Mas trairá o mandato, se agir contra a vontade do povo. A representação política, neste caso, não substi- 
tue a vontade dos representantes, mas a reproduz, a reflete, a espelha.

Mesmo quando o mandato político não seja o de querer pelo povo, mas querer com o povo, o que se observa comumente, é que os governantes tendem a impôr a sua vontade sem partilhas, a querer por si mesmos, a exercer a soberania. Raro será o que se furte á tentaçãao do poder sem peias, o que não se deixa atraír pela vertigem das alturas.

E por isto Rousseau não conciliava a representação política com a inalienabilidade da soberania.

"Eu digo, afirma ele, no Cap. I, Liv. II do Contrato Social, que, não sendo a soberania senão o exercício da vontade geral, ela não pode ser alienada, e que o soberano, que não é senão um ser coletivo, não pode ser representado senão por si mesmo: o poder é possivel transmitir-se, mas a vontade, não. Se não é impossivel que uma vontade particular coincída em alguns pontos com a vontade geral, é impossivel que este acôrdo seja duravel e constante... Porque a vontade particular tende por sua natureza para as preferencias, e a vontade geral para a egualdade".

Dahi, esta conclusão prática: "Toda lei que o povo em pessôa não a tenha ratificado, é nula, não é lei".

$\mathrm{O}$ argumento de Rousseau é impressionante. A soberania é inalienavel e suprema. Se o povo soberano delega poderes para legislar por ele, pode acontecer que tenha de vir a obedecer ao que não queira, quando tiver de cumprir lei que os representantes tenham adotado, e com a qual não concorde. Deixa então o povo de ser soberano. Na pratica a representação importa em alienação periódica da soberania. Logo a representação política é incompativel com a soberania, que não se aliena, nem mesmo por períodos.

Esmein, professor na Faculdade de Direito de Paris, desfaz o sofisma de Rousseau nesses termos: 
"A lei deve necessariamente proceder da nação, no sentido de que só a nação soberana póde fazer leis ou conferir o poder de as fazer. Mas não é verdade que a lei seja necessaria e simplesmente a expressão diréta e imediata da vontade geral, formulada de uma maneira precisa pela maioria dos cidadãos. Ela é, antes de tudo, uma regra de justiça e de interesse público. Se ela tem em sua base a autoridade do soberano, ninguem ousaria dizer que o soberano poderia decretar leis injustas ou nocivas, e o sistema de governo que, fazendo da nação a fonte constante de toda autoridade, puder melhor assegurar que tais leis não sejam votadas nem de boa fé, nem por erro, este sistema será o melhor e o mais legitimo. Proporciona o governo representativo mais ensejo que o governo diréto para lograr uma legislação justa, util, racional? Eis a questão, e ela não nos parece duvidosa".

Com quem a razão?

O silogismo com que Rousseau condena o sistema representativo, seria impecavel, se verdadeira fosse a premissa maior de que se vale. A premissa é o conceito de uma soberania idêntica á vontade geral. No Livro III, Cap. VII do Contráto Social, afirma: "A soberania consiste essencialmente na vontade geral, e esta não se representa; ela é ela mesma, ou é outra cousa; não ha meio termo"

Mas esta premissa é falsa.

$\mathrm{Na}$ realidade dos fatos, a soberania tem sido, em certos povos e certas épocas, a vontade de alguns indivíduos, ou de um só indivíduo. Tem sido, em outras épocas, a vontade geral, ou a vontade de castas. Mas, no confronto com outras realidades individuais e sociais, nada justifica que ela seja apenas a vontade geral.

Em primeiro logar, não se compreende o poder soberano, para entregar o paiz ao extrangeiro. 0 governante 
que, apoiado na vontade geral, reduzisse o povo a colónia de outro povo, seria traídor ou louco. Logo, a soberania não é o poder de tudo. Se a vontade geral fomentasse a desordem pública, quisesse a negação do direito, importasse. no império da injustiça, e abolisse a personalidade humana, esta vontade geral mais não seria que o desvario de imbecis ou dementes, um sopro pestífero dos poderes infernais. A soberania será a vontade geral, mas para a realização do bem coletivo, e nunca para semear a desgraça de todos.

Ora, se a soberania é poder supremo de assegurar o bem. de todos, não se compreende que a possa exercer quem for incapaz de conhecer o que seja e qual seja o bem de todos.

E' o povo capaz de resolver diretamente os problemas da vida e desenvolvimento de todos?

Evidentemente, não. Será capaz de escolher homens. idôneos para os resolver. Mas nunca resolver ele mesmo. Faltam-lhe capacidade, cultura e técnica, como a qualquer de nós, para não poucos problemas da vida individual.

Dahi, a representação política.

Mas representação restrita. Não, querer o representante pelo povo. Mas querer de acordo ou como o povo.

Para atalhar os abusos dos representantes contra os direitos e os interesses do povo, a experiência tem sugerido: dois grupos de medidas. . O primeiro grupo é o da separação, a limitação, a temporariedade e a responsabilidade do poder. 0 segundo é $\mathrm{o}$ da coexistência de certos institutos do governo diréto com o representativo.

São estes os institutos mais importantes.

Primeiro, o referendo popular. E' a colaboração diréta. do povo na elaboração da lei pelo parlamento. O referendo não é aquiescência do povo a um áto perfeito e acabado. Mas uma colaboração do povo na feitura da lei.

Pode o referendo ser obrigatorio ou facultativo: obrigatório é aquele sem o qual o projéto de lei não chega a ser lei. Facultativo é apenas a faculdade, que o povo se re- 
serva, de colaborar na elaboração da lei, ou tomada de resolução. Esta faculdade se exerce dentro de certo lapso de tempo, e por solicitação de certo número de cidadãos ativos. Se se escoar o prazo, sem manifestar o povo o propósito de colaborar no projeto, passa ele, depois de votado pelas câmaras, a ter força de lei, sem mais formalidades. A regra no referendo é desprezar as abstenções.

Póde, pelo seu objeto, o referendo ser constitucional ou legislativo. Constitucional o que colabora em matéria de organização e funcionamento dos poderes. Legislativo o que colabora na legislação comum.

Ainda se divide o referendo em federal, estadual, provincial ou cantonal, e municipal, ou comunal, quando a intervenção diréta do povo é na elaboração das leis ou resoluções da União, dos Estados, Provincias ou Cantões, e Municípios ou Comunas.

Combinam-se, entre si, estas espécies de referendo. Pode haver o referendo obrigatório em matéria constitucional, e facultativa em direito comum na esfera federal, ou só nas estaduais, ou em todas as esferas. Ou obrigatório nalguns casos, e facultativo em outros. As combinações são numerosas, e fáceis de verificar.

0 segundo instituto do governo diréto é o veto popular. 0 véto é a rejeição pelo povo de uma lei já ultimada. Dentro do prazo legal, certo número de cidadãos, cujo mínimo a lei determina, pede que se submeta á votação popular uma lei cuja revogação promova. E o povo póde, em votação secreta, vetal-o, ou mantel-a. Para a verificação da maioria, é mais natural, no véto, que se contem as abstenções dos votos como contrários ao véto. E' menos usado que o referendo, e como ele pode ser facultativo ou obrigatório, constitucional ou legislativo, federal, estadual ou municipal.

Terceiro instituto do governo diréto é a iniciativa popular. Não se trata de uma colaboração do povo na elaboração da lei. Mas de elaboração integral da lei ou das suas 
bases. E, como a soberania reside no povo, não ha matéria de estado que possa escapar ás iniciativas populares. Para haver ordem na votação de leis por iniciativa popular, o povo mesmo predetermina em lei as condições em que a proposta é objeto de debate, e qual o processo geral da elaboração legislativa.

As propostas de lei por iniciativa popular se apresentam sob duas fórmas. Os promotores da lei podem apresentar á assembleia legislativa o projeto redigido por inteiro, em todos os seus artigos e parágrafos, para que seja submetido ao voto popular. Nada impede que, concomitantemente, apresenta a assembleia um substitutivo, ou articule as razões por que discorda do projeto, que, por seu intermédio, vae ser votado pelo povo. E' um modo de esclarecer o assunto. 0 importante, no caso, é o direito que o povo exerce, de votar uma lei independente dos poderes constituidos.

Em logar, porém, de um projéto de leis formulado, podem os promotores solicitar á Assembleia a redação de uma lei sobre matéria que expõem, ou, se a assembleia se recusar á elaboração do projéto, submeter ao povo a questão de saber se deve ou não legislar-se no sentido da proposta. Se o povo se pronunciar pela necessidade de fazer-se a lei, já não é lícito á assembleia dos representantes insistir na recusa. Redigido o projéto, decidirá o povo sobre a sua conversão em lei.

As mesmas espécies do referendo, as iniciativas populares podem ter.

Em quarto logar, as consultas populares. Não se trata, aqui, de revogar uma lei, como no veto. Nem de sancionar, ou rejeitar um projéto de lei, como nos referendos. Nem, ainda, de elaborar uma lei com autoridade própria e exclusiva, como nas iniciativas. Mas de uma consulta dos legisladores ao povo sobre a necessidade ou conveniência de se votar certo projéto de lei, ou resolução. $O$ povo é chamado apenas a emitir seu parecer, a sua opinião, e seja 
qual for, ela não equivale á participação sua no áto legislativo, e, por isto, não obriga. E' apenas uma sondagem dos representantes no povo. O órgão legislativo, que lograr o apoio antecipado do povo a certo projéto, terá sua autoridade atualizada, para transformar tal projéto em lei. Mas, se a opinião pública se pronunciar contra, ainda é permitido aos representantes insistir na elaboração da lei. E poderão vota-la, submetendo-a, porém, ao referendo para ultima-la, ou, se já ultimada, ao veto popular.

Em quinto logar, o plebiscito. $\mathrm{E}^{\prime}$ instituto diferente de qualquer dos anteriores. 0 plebiscito é o direito do povo, sem o concurso dos poderes constituidos, de dar ou negar força de lei a proposições que lhe sejam submetidas. Foi por meio do plebiscito que Napoleão se fez imperador dos franceses. Formularam-se ao povo duas consultas: "Seria Napoleão consul vitalício"? e a segunda: "Quer o povo a hereditariedade da dignidade imperial na descendência direta, natural, legitima ou adotiva, de Napoleão Bonaparte"? 0 povo respondeu afirmativamente ás duas consultas. E assim se instituiu, na França, o imperio napoleônico.

Em sexto logar, a opção local, que é faculdade concedida a certas divisões administrativas, para adotar as leis que tenha por mais convenientes.

Em setimo logar, a revisão, dispensa popular, ou cassação popular. A cassação é o mais recente instituto do governo diréto, e tambem o mais perigoso. E' o direito que o povo tenha, de exonerar magistrados, cassar o mandato de deputados, demitir funcionários que lhe parecerem incompetentes, ou lhe caíram no desagrado, e até de reformar sentenças. Decorre esse direito do preceito de que não ha funcionario público fóra da confiança do povo. E, assim como um empregador póde dispensar os empregados que não tenham dado conta do seu recado, pode o povo cassar as funções dos representantes ou prepostos que lhe tenham cahido no desagrado. Mesmo que a nomeação do funcionário tenha sido feita pelo governo, tem o povo soberano 
o direito de o dispensar, quando o julgue ineficiênte ou relapso.

Objeta-se que a dispensa popular exerce ação nefasta sobre as convicções dos magistrados, funcionários e deputados. Para não serem exonerados, tudo fazem por contentar o povo, com sacrifício, embora, dos interesses sociais. Os demagogos, os agitadores que intrigam e caluniam, quebram, com as suas ameaças e seu prestígio popular, a resistência dos magistrados, dos funcionários, dos deputados, quando tentem opôr a justiça e a lei aos interesses mesquinhos, ás ondas da anarquia, ao capricho de potentados ou criminosos. Especialmente, a dispensa dos deputados pela cassação popular é incompativel com a representação das minorias ou opiniões ponderáveis, por isto que a maioria organizada iria depurando, pela cassação, os oposicionistas, para ficar só, na arena do poder.

A dispensa dos juizes destituiria, por seu turno, a independência da magistratura, a mais rija barreira á corrupção da democracia em demagogia. Dir-se-á que, sendo o povo quem faz a lei, a ele compete interpretal-a acima dos juizes, de modo que, quando o povo, soberano, anula a sentença de um juiz ou de um tribunal, está ele exercendo o seu direito inalienavel e imprescriptivel. Os tribunais muitas vezes pendem para a defesa dos privilégios e do capital, contra as leis egualitárias, ou os interesses do povo. Dahi, a providência ultra-democrática, de assegurar ao povo o direito, mesmo sem destituir os juizes, nem dissolver tribunais, de anular sentenças dos magistrados, embora os direitos dos cidadãos, que as sentenças assegurem, fiquem á mercê das paixões políticas, á mercê das multidốes.

Na Suissa, com excepção de Friburgo, o poder legislativo diréto do povo está parcialmente em vigor. Deve-se, ahi, distinguir o governo da federação, dos governos locais: cantôes e subcantões.

Em materia constitucional da União, nenhuma reforma ou emenda á Constituição entra em vigor, se não for aceita 
pela maioria dos cidadãos suissos, e maioria de cantões. Os votos dos semi-cantões são considerados meio voto, e o resultado da votação popular em cada cantão se considera como o voto do cantão.

Em matéria de legislação ordinária, é de uso o referendo facultativo. Se 30.000 cidadãos de 8 cantões, solicitarem, dentro de 90 dias, depois de publicadas, as leis e as resoluções federais, que não tiverem caracter de urgência, são submetidas á adoção ou rejeição do povo.

Tambem a iniciativa popular está em vigor na Suissa, para matéria constitucional.

As revisões parciais da constituição suissa podem ser feitas por meio da iniciativa popular. A iniciativa começa por um pedido de 50 mil cidadãos ativos, que reclamem a adoção de um novo artigo, ou a revogação de artigos em vigor. Ou se faz o pedido em termos gerais, iniciativa não formulada, ou em redação articulada, iniciativa formulada. No primeiro caso, as câmaras federais, a dos representantes e a dos cantões, se estiverem de acôrdo, procedem á revisão no sentido indicado, e submetem o projéto á aprovação ou rejeição do povo e dos cantões. Se não estiverem de acôrdo os representantes, a questão da revisão parcial será submetida á votação popular, e se a maioria dos cidadãos estiver pela reforma, a assembléia' federal fará a revisão, conformando-se com a decisão popular. No segundo caso, isto é, quando o pedido se apresenta redigido artigo por artigo, ainda se podem verificar as duas hipoteses: ou a assembléia está ou não está de acôrdo. Se estiver, o projéto será submetido á adoção ou á rejeição do povo; se não estiver, ela pode elaborar um projéto distinto, que apresentará conjuntamente ao povo, para que se pronuncie sobre a divergência.

Tratando-se de uma revisão total da Constituição, é obrigatório submeter-se a proposta a um plebiscito. Primeiramente, a proposta terá de ser assignada por $50 \mathrm{mil}$ cidadãos no mínimo. Mas, antes de entrar em votação a 
proposta, o povo tem de resolver, sim ou não, se a constituição federal deve ser revista. Se, por maioria de votos, a opinião pública fôr pela revisão, a reforma terá de ser feita. O projéto da nova constituição será formulado pelos conselhos legislativos, por isto que não são formuladas as iniciativas de reforma total da constituição.

O direito de iniciativa não se compreende, em principio, que possa ser limitado. Seria limitar a propria soberania. $\mathrm{E}$ quem teria em mãos o poder, acima do povo, para lhe opôr barreira á vontade soberana? Sendo o povo, com a iniciativa popular, o orgão mais importante do estado, a consequência é que a iniciativa tem que ser onipotente. Mas, para atalhar a confusão de poderes, a iniciativa é disciplinada e processada por leis, e, pois, não póde exercer-se contra a constituição ou as leis. Seria preciso, primeiro, reformar os textos constitucionais que a disciplinem. Não se compreende, por exemplo, que, pela iniciativa constitucional, o povo se substitua ao poder judiciário. As iniciativas são, antes de mais, legislativas, posto se possam admitir iniciativas em matéria administrativa. Em doutrina pura e abstráta, o povo poderia substituir-se até ao poder judiciário. E estaria certo, se o povo fosse de semi-deuses. Mas, sendo de homens, com todos os percalços e defeitos da natureza humana, o poder soberano provavelmente se desnaturaria na prática, se fosse exercido diretamente pelo povo em questões básicas, e, principalmente, em pleitos judiciais.

$\mathrm{Na}$ Suissa, o direito de iniciativa não existe em matéria legislativa, e isto porque acarretaria as maiores dificuldades práticas no mecanismo da federação. Uma lei ordinária, elaborada pelos representantes, não é aprovada sem o apoio do conselho dos cantões. Se fosse, porém, ela objéto de iniciativa popular, o projéto adquiriria força de lei, desde que fosse aceito pela maioria dos cidadãos votantes. $\mathrm{E}$, na federação, não basta a representação popular para se haverem leis. $E^{\prime}$ indispensavel a votação dos estados ou 
cantões. Suprimir esta votação seria quebrar uma das vigas mestras da federação. Logo, as iniciativas populares, em matéria não constitucional, são impraticáveis no governo central das federações.

Nos cantões, o referendo constitucional é obrigatório, isto é, todas as reformas ou emendas ás constituições cantonais, têm de ser submetida á adoção ou rejeição do voto popular nos respectivos cantões.

Nos' cantões, tambem as constituições podem ser modificadas por meio de iniciativas populares. E o processo destas iniciativas é mais simples que a das iniciativas para a reforma total ou parcial da constituição federal.

Já em matéria legislativa, o referendo nem sempre é obrigatório nos cantões. Nalguns é facultativo. E, em todos, existe o direito de iniciativa popular. Cada um o regulamentou a seu modo. Por iniciativa popular, em alguns cantões, podem até ser dissolvidos o Conselho Legislativo e o Conselho Executivo.

Nas comunas de um grande numero de cantões, vigoram instituições de democracia diréta. Em muitos, subsistem assembléias comunais, que são verdadeira "landsgmeind" locais, e, em outros, os referendos e as iniciativas.

Tambem nos Estados Unidos, se praticam algumas instituições de governo direto. Importa lembrar que os Estados Unidos adotaram o regimen federativo, pelo qual os 48 estados que se uniram, gosam de uma autonomia cujas raias fronteirizam na soberania.

Ao contrário da Suissa, a constituição estadunidense não obriga os estados federados a submeter ao voto popular suas respectivas constituições. Isto se faz, ao se converter um território em estado. A regra, porem, é que toda revisão constitucional, nos estados, é submetida ao voto dos eleitores. $\mathrm{O}$ referendo é obrigatório, quando se trata de emendas ás constituições dos estados federados. Quando se trata de reforma total, o povo elege uma convenção para elaborar o projéto, que será submetido ao referendo. 
Em matéria de legislação ordinária, muitos estados americanos adotam o referendo obrigatório, e outros o facultativo. Em todos os casos, porém, podem as camaras dos representantes subtrair á votação popular as leis que tenham por urgentes, como as referentes á segurança pública e á higiene.

$O$ veto popular é adotado no estado do Novo Mexico da União Americana. Em logar de referendo, com que poderia participar na formação das leis, pode o povo do Novo Mexico revogar uma lei já em execução.

Em quinze estados da União Americana, as respectivas constituições podem ser emendadas por meio da iniciativa popular. Em vinte e dois, o povo tem a iniciativa da legislação ordinária.

Alem destes institutos, ainda ha, em certos estados, dois outros: a opção local cujo uso precede ao do referendo e da iniciativa, e a cassação (recall) com o qual o povo destitúe funcionários de seus cargos, ou anula sentenças do poder judiciário, passando assim a ter valor constitucional preceito que os tribunais tivessem taxados de inconstitucionais.

Na esfera do governo federal, porém, nenhum destes institutos foi adotado: o sistema representativo impéra, ahi, sem partilhas.

Fóra da Suissa, dos Estados que constitue a União Americana, os institutos do governo diréto são rejeitados quasi por toda parte, ora pelas autocracías, ora pelas democracias puramente representativas. Encontram-se, aqui e alí, reminiscencias de plebiscitos, vestígios e, mesmo, algumas práticas tímidas do referendo e da iniciativa, como na Estónia, na Letónia e na Lituânia.

$O$ que a experiência nos ensina, afinal, é que os institutos do governo diréto podem coexistir com a democracia representativa.

$\mathrm{E}$ razões especiais pleiteiam esta coexistência para a defesa da soberania do povo contra excessos do poder representado, ainda quando tenha o governo representativo 
os contrapesos que o circumscrevam dentro das raias da vontade popular.

A primeira é que é mais dificil corromper a maioria dos cidadãos, que um grupo reduzido de deputados ou ministros de estado. Sobretudo quando se trate de medidas contra grandes organizações de industrias, os trustes poderosos e absorventes. 0 povo dicide com mais energia.

A segunda é que os próprios representantes, sentido atraz de si a fiscalização do povo, que lhe pode vetar ou referendar as resoluções, ou tomar a iniciativa delas, levam mais a serio os seus deveres, e se lhes apura mais o sentimento da responsabilidade.

A terceira é que os referendos e as iniciativas populares obstam á formação das oligarquias oficiais, que senhoreiem o paiz. O povo, pelo voto da maioria dos cidadãos, tem sempre a palavra final.

A quarta é que, podendo o povo vetar leis orçamentárias, ou subordinar o orçamento ao referendo obrigatório, o povo se opõe ao excesso de despezas, evita o desperdício dos dinheiros públicos, sangria demasiada ao seu trabalho.

A quinta é que se consolida mais o melhor a liberdade econômica, o regimen das iniciativas individuais, sem prejuizo do império da justiça nos contratos de trabalho. A economia dirigida, as autarquias administrativas que suprimem as iniciativas individuais, não chegam a nascer.

A sexta é que, com o referendo e o véto, pode o povo opôr resistencia ás demasias do poder executivo, em resolações que tome, ou quando entre o parlamento a estatuir leis ditatoriais.

Doutro lado, levantam-se objeções muito sérias.

A mais grave é a da irresponsabilidade popular. A democracia direta é, no fundo, o governo das multidões, e este é o peior de todos os governos. 0 poder illimitado da massa anônima é a ruina inevitavel da civilização. 
Em seguida, sabe-se que o povo é mais egoista que patriota, fica indiferente ás grandes reformas políticas e sociais, que não lhes interessem diretamente os celeiros 0 ideal social não marcharia.

E porque, argumenta-se, não substituir os institutos da democracia diréta, por providências cada vez mais amplas, graças ás quais é o povo que tem a palavra última, mas dentro da disciplina, da ordem e do bom senso?

Porque, por exemplo, em logar dos institutos do governo diréto, que enfraquecem, desautoram e desmoralizam os parlamentos, não preferir, como a Inglaterra, as eleições gerais, sempre que se trate de uma lei que transforme profundamente a constituição, ou mude radicalmente a orientação política do governo? Este apelo ao corpo eleitoral abre portas a que o povo manifeste sua opinião atual sobre a reforma constitucional, ou a mudança da orientação política do governo.

O mesmo, como entre nós, a exigência de duas legislaturas para a revisão do que for orgânico nas leis constitucionais.

Dir-se-á que não equivalem as eleições gerais aos institutos de referendo, ou da iniciativa. Nas eleições gerais, os cidadãos votam em indivíduos cujas ideias sobre o caso em debate lhes inspiram confiança, mas nem sempre sobre os casos, os problemas que se seguirão necessariamente, ao passo que, com o referendo ou a iniciativa, o povo se pronuncia sobre cada questão concreta, e não ha perigo de ser ludibriado com as ideias, ou trahido com as mutações dos candidatos. Uma vez que se quer conhecer a opinião da maioria dos eleitores sobre uma questão determinada, não ha como o referendo, a iniciativa, ou o plebiscito que a traduzem, inequivocamente, sim ou não.

Mas os argumentos realmente impressionantes contra a democracia diréta são: primeiro, a incapacidade popular para resolver diretamente os problemas públicos, ainda que capaz de escolher quem os resolva com acerto; e, segundo, 
o de que ela assegura a dominação absoluta da maioria popular, que pode ignorar o direito e o interesse real. A minoria viveria oprimida pela maioria macissa. E sabe-se que nem sempre é com o número que está a razão. Pode mesmo acontecer que a maioria, identificando a soberania com a sua vontade, só se delibere por interesses individuais. Tal, por exemplo, o caso de uma formidavel maioria proletária que, lisongeada pelos demagogos, fosse, por uma propaganda tenaz, como a bolchevista, ou fascista, levada á adoção do comunismo da direita ou da esquerda, que lhe acenam com a terra prometida da redenção, da fartura e da ordem. E não bastará a possibilidade do despotismo e da intolerância, para se condenar a democracia diréta? ou, mesmo, a coexistência, com a representação, de certos institutos do governo diréto? 